\title{
REVITALISASI PEKARANGAN LANSKAP PERDESAAN SEBAGAI PENYEDIA JASA LANSKAP UNTUK MENINGKATKAN KESE- JAHTERAAN MASYARAKAT
}

\begin{abstract}
Revitalization of Rural Landscape
Homegarden "Pekarangan" as

Landscape Services Provider to Improve Community Welfare
\end{abstract}

\section{Kaswanto}

Staf Pengajar Departemen Arsitektur Lanskap, Fakultas Pertanian, IPB

E-mail: kaswanto@ipb.ac.id

\section{Tataq Aisyah Filqisthi}

Mahasiswa Departemen Arsitektur Lanskap, Fakultas Pertanian, Institut Pertanian Bogor (IPB)

\section{Bagus Suryono Choliq}

Mahasiswa Departemen Arsitektur Lanskap, Fakultas Pertanian, Institut Pertanian Bogor (IPB)

\begin{abstract}
A robust management for Indonesian typical home garden or usually called as "pekarangan" is needed to resolve environmental problems in rural landscape, particularly in developing countries. A well planned and managed landscape practices may suppress social economical and ecological development in rural marginal society. Therefore by revitalizing pekarangan systems, marginal communities would have the possibility to advance their asset of landscape services through plant biodiversity $\left(H^{\prime}\right)$ and carbon stock $(C)$ inside pekarangan. The aim of this research is to develop basic landscape service of plant biodiversity and carbon stock, to analyze the correlation between both of them, and to arrange recommendation for revitalizing pekarangan. The results show that pekarangan has diverse plant biodiversity (0.77-3.57) and diverse carbon stock (0.13-136.20 $\mathrm{Mg} / \mathrm{ha}$. However plant diversity in mid to high scale $\left(H^{\prime}>1.00\right)$ reach $98.95 \%$ and high carbon stock (C>10.00 Mg/ha) reach $45.83 \%$. And there is positive correlation among both of them $(Y=0.0099 X+2.0299)$. Those landscape services provided by pekarangan account to mimic forestry landscape.
\end{abstract}

Keywords: carbon stock, landscape management, low carbon landscapes, plants biodiversity, watershed management.

\section{PENDAHULUAN}

\section{Latar Belakang}

Revitalisasi pekarangan menuju lanskap rendah karbon (low carbon landscapes - LCL) adalah sebuah konsep dalam menjawab permasalahan manajemen lanskap dari berbagai disiplin ilmu. Pekarangan pada lanskap perdesaan menyediakan berbagai jenis jasa lanskap yang pada akhirnya mampu meningkatkan kesejahteraan masyarakat. Penataan pekarangan sebagai proses lanskap sosial budaya harus dipertimbangkan sebagai fungsi ekologis yang berkelanjutan. Penataan pekarangan dapat diinvestigasi pada skala makro (macro-scale), skala meso (meso-scale) dan skala mikro (micro-scale). Skala makro difokuskan pada dua daerah aliran sungai (DAS), skala meso pada zona hulu-tengahhilir dari DAS, dan skala mikro pada pekarangan itu sendiri.

Pekarangan merupakan salah satu bentuk lanskap agroforestri yang sangat representatif. Lanskap agroforestri kerap didefinisikan sebagai kombinasi lanskap pertanian dan kehutanan yang dikelola sedemikian rupa untuk menciptakan keseimbangan antara intensifikasi pertanian dan kelestarian kehutanan. Lanskap agroforestri juga kerap dikembangkan dalam pengelolaan lahan yang complex yang pada akhirnya mampu mengoptimalkan keuntungan keberlanjutan baik dari aspek ekologi dan sosial yang timbul akibat interaksi biologis ketika organisme didalamnya berkembang secara efektif. Pekarangan dapat diartikan sebagai lanskap agroforestri skala mikro, karena di dalam pekarangan dapat dijumpai tanaman tahunan dan semusim, termasuk di dalamnya terdapat ternak yang dibudidayakan secara efektif. Beberapa penelitian membuktikan bahwa pekarangan mampu menyediakan berbagai jenis jasa lanskap yang sangat bermanfaat, mulai dari produktivitas dan biodiversitas tanaman, kandungan karbon tersimpan, manajemen sumber daya air, hingga keindahan lanskap. Pada artikel ini, jasa lanskap yang diamati berupa biodiversitas tanaman (plant biodiversity) dan karbon tersimpan (carbon stock).

Pekarangan diasumsikan sebagai taman rumah, halaman ataupun ruang terbuka yang ada di sekeliling rumah. Pekarangan juga didefiniskan sebagai sistem agroforestri yang kompleks kaya dengan beragam spesies perpaduan tanaman tahunan dan semusim dengan struktur vertikal multistrata, dan kerap dikombinasikan dengan ternak (Soemarwoto 1987, Christanty 1990). Pekarangan merupakan kumpulan tanaman, termasuk pohon, semak, perdu dan tanaman merambat yang ada di halaman rumah (Landauer and Brazil 1990). Beragam jenis produk yang multiguna dapat dihasilkan dari pekarangan dengan kebutuhan tenaga kerja, biaya dan input lainnya yang relatif rendah (Christanty 1990, Soemarwoto and Conway 1992, Hochegger 1998). Lebih lanjut, pekarangan juga disebutkan berkontribusi secara nyata dalam siklus karbon tersimpan dan pada saat yang bersamaan juga meningkatkan kesejahteraan masyarakat perdesaan (Arifin and Nakagoshi 2011).

Besarnya manfaat pekarangan seperti yang disebutkan di atas ternyata belum berkorelasi secara positif dengan pemanfaatan yang ada saat ini. Sebagian besar pekarangan tidak dikelola dengan baik, bahkan ada pekarangan yang sedikitpun tidak menyediakan jasa 
lanskap biodiversitas dan karbon tersimpan secara alami. Untuk itu, penelitian ini menitikberatkan bagaimana kaitan antara biodiversitas dan karbon tersimpan pada lanskap pekarangan sedemikian rupa sehingga dapat dikelola secara berkelanjutan.

\section{Tujuan}

Penelitian ini memiliki tiga tujuan yang berkaitan dengan jasa lanskap (landscape services) yang disediakan oleh pekarangan sebagai salah satu bentuk praktik lanskap agroforestri. Ketiga tujuan tersebut adalah 1) mengukur indeks biodiversitas $\left(\mathrm{H}^{\prime}\right)$ dalam pekarangan, 2) menganalisis karbon tersimpan (C) pada pekarangan, dan 3) merumuskan rekomendasi manajemen yang baik untuk pekarangan yang berkelanjutan berdasarkan analisis korelasi jasa lanskap biodiversitas dan karbon tersimpan.

\section{METODE}

\section{Lokasi dan Waktu Penelitian}

Penelitian dilakukan di dua buah DAS di kawasan Jawa bagian barat, tepatnya di DAS Cisadane dan Ciliwung (Gambar 1). Pemilihan lokasi ini didasarkan atas pertimbangan, 1) area hulu DAS yang sama sehingga diasumsikan memiliki elevasi yang sama, 2) orientasi yang sama, yakni arah utara yang digunakan sebagai analisis perbandingan, 3) efek urbanisasi yang tinggi, karena dua kawasan DAS ini memiliki tingkat pertumbuhan penduduk dan pembangunan yang paling besar.

DAS Cisadane meliputi beberapa kabupaten dan kota di Propinsi Jawa Barat, Propinsi DKI Jakarta, serta Kabupaten dan Kota Tangerang, Propinsi Banten. Tiga kabupaten atau kecamatan yang diambil sebagai sampel adalah Kecamatan Ciampea di bagian hulu, Kecamatan Ciseeng di bagian tengah dan Kecamatan Karawaci di bagian hilir. DAS Ciliwung mencakup Propinsi Jawa Barat dan DKI Jakarta, sampel penelitian berada di Kecamatan Cisarua di bagian hulu, Kecamatan Cibinong di bagian tengah dan Kecamatan Tebet di bagian hilir. Secara umum DAS Cisadane dan Ciliwung beriklim lembab dengan curah hujan $2000 \mathrm{~mm} /$ tahun (BMKG Jawa Barat 2016).

\section{Metode Pengambilan Sampel Pekarangan}

Dalam penelitian ini, pendekatan ekologi lanskap (Gambar 2) digunakan untuk menganalisis seluruh proses lanskap agroforestri pada pekarangan (Kaswanto et al. 2013), yakni untuk menilai ketersediaan jasa lanskap yang berkaitan dengan 1) konservasi keanekaragaman hayati tanaman (plants biodiversity conservation), 2) jumlah karbon tersimpan (carbon stock value), dan 3) manajemen lanskap (landscape management) pada pekarangan. Proses penelitian menggunakan metode pengukuran langsung dan wawancara. Metode dilakukan dengan perspektif ekologi lanskap melalui skala mikro dalam pekarangan. Perhitungan jumlah sampel pekarangan diawali dengan jumlah dua DAS, kemudian pada setiap DAS terdapat tiga sub-DAS yakni hulu, tengah dan hilir. Pada setiap sub-DAS dipilih dua desa dan kemudian pada setiap desa dipilih satu dusun. Pada setiap dusun dilakukan pengukuran pada empat pekarangan. Pada akhirnya, sebanyak 96 (sembilan puluh enam) sampel pekarangan telah diukur secara langsung dan diwawancarai untuk melihat potensi keragaman tanaman dan kandungan karbon

Penentuan sampel pekarangan di dalam dusun dibagi menjadi empat grup, yakni G1, G2, G3 dan G4 (Tabel 1). Pemilihan sampel dilakukan dengan 1) pemilihan desa secara acak, 2) mengevaluasi ada tidaknya praktik

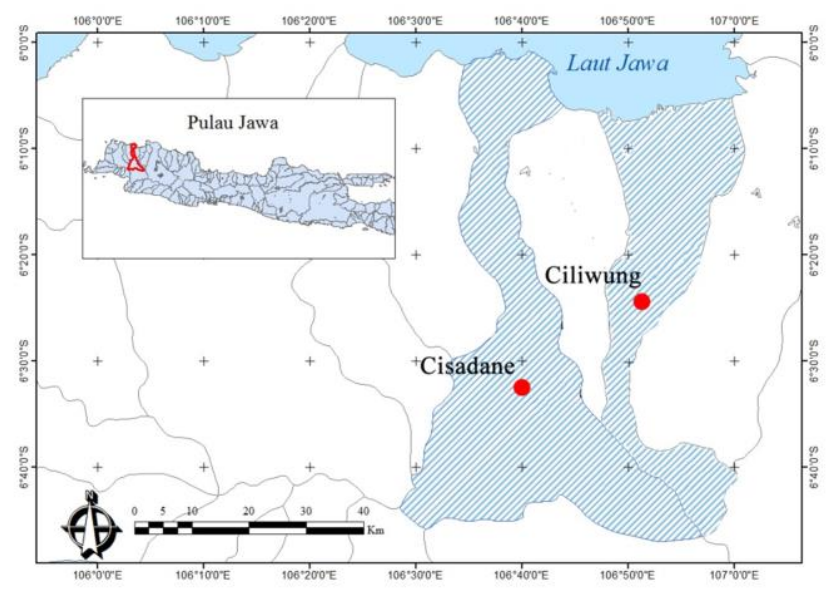

Gambar 1. Lokasi penelitian di dua daerah aliran sungai (DAS) di kawasan Jawa bagian barat, yakni DAS Cisadane dan Ciliwung.

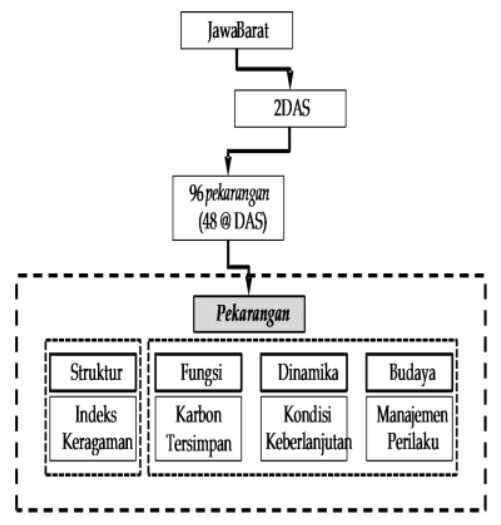

Gambar 2. Pendekatan ekologi lanskap menganalisis empat aspek yakni, 1) struktur, 2) fungsi, 3) dinamika, dan 4) budaya yang ada di dalam lanskap agroforestri skala mikro (pekarangan). 
KASWANTO, FILQISTHI, CHOLIQ

Tabel 1. Penentuan sampel pekarangan berdasarkan luas pekarangan dan kepemilikan Other Agricultural Land (OAL).

\begin{tabular}{ccc}
\hline Grup & Luas Pekarangan $\left(\mathrm{m}^{2}\right)$ & Kepemilikan Other Agricultural Land (OAL) \\
\hline G1 & $<120$ & Tanpa OAL \\
\hline G2 & $<120$ & Memiliki OAL $<1.000 \mathrm{~m}^{2}$ \\
\hline G3 & $120-400$ & Tanpa OAL \\
\hline G4 & $120-400$ & Memiliki OAL $<1.000 \mathrm{~m}^{2}$ \\
\hline
\end{tabular}

Tabel 2. Persamaan Alometrik yang digunakan untuk mengetahui kandungan biomassa tanaman.

\begin{tabular}{|c|c|c|}
\hline Jenis Tanaman & Persamaan Alometrik & Sumber \\
\hline Jati (Tectona grandis) & $Y=0,153$ D2,39 & Hairiah et al (2011) \\
\hline Pisang (Musa sp.) & $Y=0,0303 \mathrm{D} 2,1345$ & Hairiah et al (2001) \\
\hline $\begin{array}{l}\text { Multispecies untuk semak dan pohon D } \\
\qquad<5 \mathrm{~cm}\end{array}$ & $\operatorname{Ln}(A G B)=-3,50+1,65 \operatorname{Ln}(\mathrm{D})+0,842 \operatorname{Ln}(\mathrm{H})$ & Ali et al (2015) \\
\hline Pohon lainnya & $Y=42,69-12,8 \mathrm{D}+1,242 \mathrm{D} 2$ & Chave et al (2005) \\
\hline
\end{tabular}

intensifikasi dalam pekarangan, dan 3) mendefinisikan kerangka sampel (sample frame) pekarangan yang mempunyai hak kepemilikan dan jenis pemanfaatan lahan yang dominan, seperti produksi pertanian dengan hortikultura, atau tanaman pangan dengan peternakan, ataupun jenis penggunaan intensif lainnya. Sebelum pengumpulan data responden, kerangka sampel terlebih dahulu dibuat. Kerangka sampel adalah jumlah pekarangan di setiap dusun yang sesuai dengan kriteria prosedur empat grup yang telah disebutkan di atas. Metode pengambilan contoh seperti ini dikatakan sebagai purposive random sampling.

\section{Analisis Indeks Biodiversitas Tanaman}

Analisis vegetasi dilakukan untuk menghitung indeks biodiversitas tanaman yang ditemukan di pekarangan. Prosedur analisis vegetasi adalah sebagai berikut, 1) menentukan pekarangan yang akan menjadi sampel, 2) mencatat dan mengidentifikasi jenis tanaman, dan 3) menghitung indeks nilai penting dan nilai keanekaragaman Shannon-Wiener dengan menggunakan Microsoft Excel.

Indeks biodiversitas (Shannon-Wiener Index) merupakan rumus untuk menghitung keanekaragaman, yaitu suatu gabungan antara jumlah jenis dan jumlah individu masing-masing jenis dalam satu pekarangan, dengan formulasi sebagai berikut:

$H^{\prime}=-\left\{\sum \rho i \ln \rho i\right\}$ dimana $\mathrm{pi}=\mathrm{ni} / \mathrm{N}$

dengan:

$$
\begin{array}{ll}
\mathrm{H}^{\prime} & =\text { Indeks Shannon-Wiener } \\
\mathrm{pi} & =\text { Kelimpahan Relatif } \\
\mathrm{n}_{\mathrm{i}} & =\text { Jumlah Spesies (i) } \\
\mathrm{N} & =\text { Total Jumlah Individu }
\end{array}
$$

Hasil akhir Indeks Shannon-Wiener dibagi menjadi tiga kriteria, yaitu :

$$
\begin{array}{ll}
\mathrm{H}^{\prime}<1 & =\text { Keanekaragaman Rendah } \\
1<\mathrm{H}^{\prime}<3 & =\text { Keanekaragaman Sedang } \\
\mathrm{H}^{\prime}>3 & =\text { Keanekaragaman Tinggi }
\end{array}
$$

\section{Analisis Pengukuran Karbon Tersimpan}

Analisis pengukuran karbon tersimpan didekati dengan analisis biomassa tanaman. Dalam perhitungan biomasa tanaman digunakan metode non-destruktif (undestructive method) dengan menggunakan persamaan alometrik berdasarkan spesies tanaman yang terdapat dalam pekarangan. Alometrik adalah suatu fungsi matematika yang menunjukkan hubungan antara bagian tertentu dari makhluk hidup tersebut. Persamaan tersebut digunakan untuk menduga parameter tertentu dengan menggunakan parameter lainnya yang lebih mudah diukur, dalam hal ini adalah menduga biomasa pohon dengan mengukur diameter batang pohon tersebut (Hairiah and Rahayu 2007). Rumus alometrik pendugaan biomassa tanaman (Hairiah and Rahayu 2007) secara umum yaitu:

$Y=a \cdot D B H^{b}$

dengan:

$$
\begin{array}{ll}
\mathrm{Y} & =\text { Biomassa tanaman } \\
\mathrm{DBH} & =\text { Diameter Breast Height }(1,35 \mathrm{~m}) \\
\mathrm{a} & =\text { Koefisien konversi } \\
\mathrm{b} & =\text { Koefisien alometrik }
\end{array}
$$

Rumus alometrik yang digunakan pada penelitian ini merupakan persamaan alometrik pohon yang telah dikembangkan oleh Hairiah dan Rahayu (2007) dan Chave et al (2005), sedangkan untuk semak 
digeneralisasi menggunakan persamaan Ali et al (2015) (Tabel 2). Pendugaan karbon tersimpan pada tanaman herba menggunakan hasil dari penelitian Roshetko (2002, 2007) yang telah melakukan sampling melalui pemanenan (destructive sampling) pada lahan pekarangan di daerah Lampung dengan rata-rata $0,3 \mathrm{Mg} / \mathrm{ha}$. Kemudian pendugaan kandungan karbon di atas permukaan tanah pada pekarangan menggunakan rumus menurut Brown (1997), yaitu:

$C=Y \times 0,5$

dengan:

$\mathrm{C}=$ Kandungan karbon di atas permukaan tanah $(\mathrm{kg})$

$Y \quad=$ Nilai biomassa $(\mathrm{kg})$

$0,5=50 \%$ karbon tersimpan dalam biomassa

Analisis Korelasi Indeks Biodiversitas dengan Karbon Tersimpan

Analisis korelasi antara indeks biodiversitas tanaman $\left(\mathrm{H}^{\prime}\right)$ dengan karbon tersimpan $(\mathrm{C})$ dilakukan dengan persamaan linear regresi sederhana. Metode statistik ini berfungsi untuk menguji hubungan sebab akibat antara variabel bebas $\left(\mathrm{H}^{\prime}\right)$ terhadap variabel tak bebas (C). Indeks biodiversitas tanaman adalah variabel bebas, sedangkan karbon tersimpan pada tanaman adalah variabel tak bebas. Model persamaan linear regresi adalah sebagai berikut:

$$
H^{\prime}=a C+b
$$

dengan :

$\mathrm{H}^{\prime}=$ Indeks biodiversitas: variabel tak bebas

$\mathrm{C}=$ Kandungan karbon tersimpan: variabel bebas

$\mathrm{a}=$ koefisien regresi

$\mathrm{b}=$ konstanta

\section{HASIL DAN PEMBAHASAN}

\section{Indeks Biodiversitas Tanaman dalam Pekarangan}

Hasil pengamatan mengidentifikasi ditemukan sebanyak 265 jenis tanaman dari 80 famili dengan klasifikasi delapan fungsi yaitu tanaman hias, tanaman industri, tanaman penghasil pati, tanaman obat, tanaman bumbu, sayur-mayur, buah, dan lainnya. Jumlah ini lebih besar dari penelitian sebelumnya yang dilakukan di empat DAS Jawa Barat yaitu 214 spesies (Kaswanto and Nakagoshi 2014). Jumlah ini juga lebih besar, jika dibandingkan dengan beberapa penelitian pekarangan pada kawasan tropis lainnya, pekarangan Santa Rosa di
Peruvian Amazon dengan 168 spesies (Padoch and de Jong 1991) dan di pekarangan Thailand utara dengan 230 species (Moreno-Black et al. 1996), serta Kenya bagian barat 253 spesies (Backes 2001). Namun hasil ini lebih kecil dari daerah lain di Jawa Barat yaitu DAS Cianjur sebesar 440 spesies (Arifin et al. 2014), Zaire 272 spesies (Mpoyi et al. 1994), dan Nikaragua 324 spesies (Méndez et al. 2001). Bahkan, secara keseluruhan jumlah terbanyak di daerah Jawa Barat terdapat 602 spesies (Karyono 1990) dan hampir $40 \%$ tanaman tercatat dari jumlah tersebut.

Struktur horizontal pekarangan dengan indeks biodiversitas yang tinggi terkait dengan jumlah dan jenis tanaman hias (ornamental plants) yang sangat beragam. Tanaman dalam pekarangan didominasi oleh tanaman hias yang mencapai $49,01 \%$. Hal ini menunjukkan bahwa ada preferensi pemilik pekarangan untuk lebih memanfaatkan pekarangan sebagai kepentingan estetika semata. Sementara untuk kebutuhan akan pati (karbohidrat), sayuran, bumbu maupun industri masih relatif rendah (Gambar 3). Berdasarkan fungsi tanaman, di dalam pekarangan ini terdapat tanaman buah mangga, tanaman pagar Pachystachys lutea (lolipop), serta tanaman hias anggrek Phalaenopsis sp., dan tanaman $A n-$ thurium sp.

Struktur vertikal pekarangan memperlihatkan bahwa sebagian besar biodiversitas didominasi dengan tanaman Stratum II antara 1 hingga $2 \mathrm{~m}(45,3 \%)$. Walaupun demikian, tanaman dengan tinggi lebih dari $2 \mathrm{~m}$ (Stratum III, IV dan V) mencapai lebih dari $20 \%$, artinya kapasitas ruang dalam pekarangan memungkinkan tanaman untuk tumbuh vertikal secara optimal (Gambar 3). Contohnya tanaman Crinum moorei (bakung) pada stratum I, tanaman Codiaeum sp. (puring) pada stratum II, dan tanaman Mangifera indica (mangga) pada stratum III. Kondisi ekologi dari keragaman horizontal dan vertikal memperlihatkan bahwa pekarangan sangat berkontribusi dalam mempertahankan keberlanjutan lingkungan (Kaswanto and Nakagoshi 2011). Hylander dan Nemomissa (2009) juga menyimpulkan bahwa komposisi spesies dari sebuah pekarangan kadangkala menyerupai area hutan tanaman.

Indeks keragaman spesies ditunjukkan oleh jumlah spesies dan individu tanaman yang ditemukan dalam 96 sampel pekarangan. Sebagian besar struktur pekarangan yang menjadi responden ditemukan hampir menyerupai kondisi forestry landscape, di mana keragaman vertikal dan horizontal relatif tinggi dengan nilai $\mathrm{H}^{\prime}$ pada skala keanekaragaman sedang (Gambar 4). Nilai $\mathrm{H}^{\prime}$ berkisar dari $0,77-3,57$, namun nilai $\mathrm{H}^{\prime}>1,00$ mencapai $98,95 \%$ dari total sampel pekarangan. Pekarangan G1 dan G3 adalah gambaran kepemilikan pekarangan tanpa memiliki lahan lain di luar pekarangan (Other Agricultural 
Land - OAL), dan pekarangan G2 dan G4 adalah gambaran kepemilikan pekarangan dengan memiliki OAL. Rataan indeks biodiversitas pada pekarangan tanpa OAL (G1\&G3) lebih tinggi daripada pekarangan dengan OAL (G2\&G4). Hal ini menunjukkan bahwa, dengan tidak adanya OAL akan membuat pemilik rumah memanfaatkan lahan pekarangannya secara intensif, sehingga membuat biodiversitas pada pekarangan tanpa OAL lebih tinggi. Kebanyakan pekarangan tanpa OAL menanam tanaman pangan dan tanaman obat yang bisa digunakan untuk memenuhi kebutuhan pangan keluarga atau menambah pendapatan. Karyono (1990) menyatakan pekarangan tanpa lahan sawah dapat difungsikan sebagai lahan penghasil karbohidrat dengan menanam tanaman seperti singkong dan ubi. Lebih lanjut, disebutkan bahwa beberapa penelitian menyatakan produksi pekarangan juga berkontribusi menghasilkan kalori, protein, vitamin A dan C (Christanty 1986, Christanty et al. 1986, Niñez 1987, Soemarwoto and Conway 1992, Mulyoutami et al. 2009, Arifin et al. 2014, Kaswanto and
Nakagoshi 2014). Pendapatan dari lahan pekarangan diperoleh dari menjual buah-buahan dan tanaman lainnya yang berasal dari pekarangan.

Pekarangan dengan nilai biodiversitas tinggi cenderung terpelihara (Gambar 5). Pemilik rumah selain memanfaatkan lahan pekarangan secara intensif, mereka juga memiliki kebiasaan atau kesukaan (hobi) yang terkait dengan tanaman atau berkebun. Pekarangan bagian depan kerap ditanami dengan tanaman hias, tanaman pagar, dan juga pohon kersen sebagai peneduh. Sayuran, tanaman obat dan bumbu berada di pekarangan samping rumah. Hal ini memberikan dampak positif bagi pengelolaan pekarangan. Christanty et al (1986) menyatakan tanaman hias biasanya diletakkan di pekarangan bagian depan begitu pula tanaman bernilai ekonomis seperti pohon berbuah sehingga pemilik dapat melihat tanaman-tanaman tersebut, selain itu tanaman obat, penghasil pati dan sebagainya biasa ditanam di pekarangan bagian depan ataupun belakang.

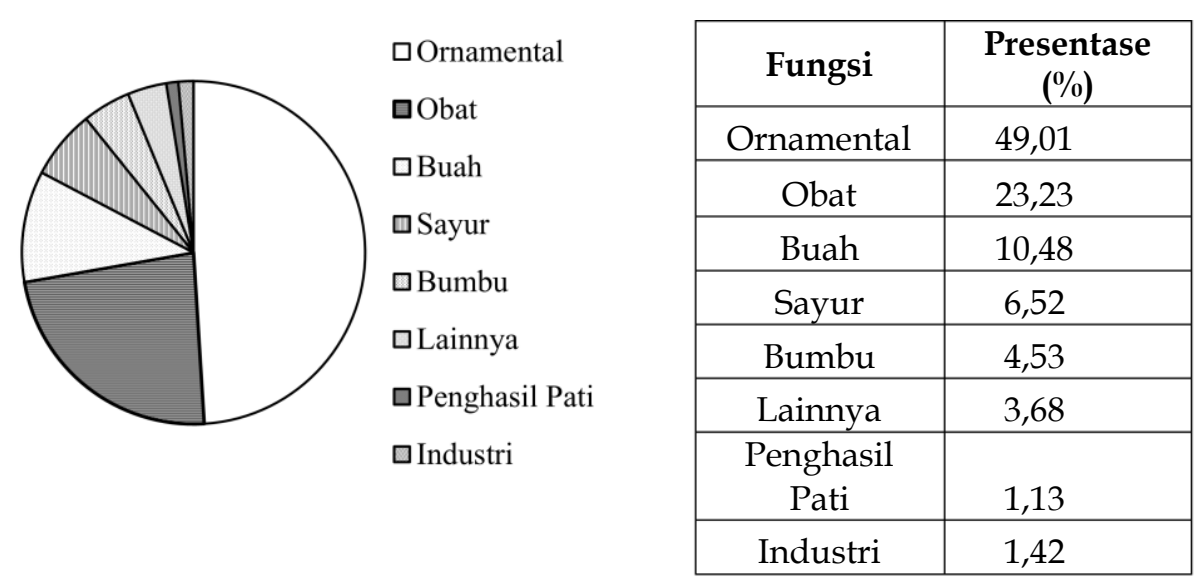

(a) Kategori tanaman pada keragaman horizontal (fungsi tanaman)

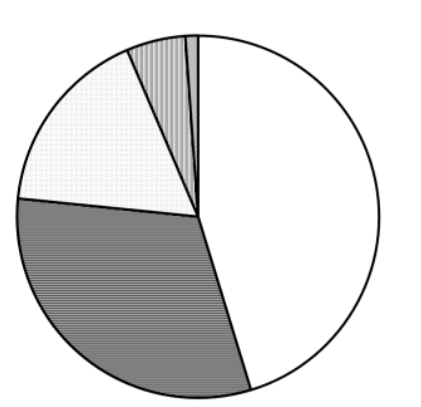

II : 1-2 m

$\square \mathrm{I}: 0-1 \mathrm{~m}$

III : $2-5 \mathrm{~m}$

$\square$ IV : $5-10 \mathrm{~m}$

$\square \mathrm{V}:>10 \mathrm{~m}$

\begin{tabular}{|c|c|}
\hline $\begin{array}{c}\text { Strata } \\
\text { Tanaman }\end{array}$ & $\begin{array}{c}\text { Presentase } \\
\mathbf{( \% )}\end{array}$ \\
\hline $\mathrm{II}: 1-2 \mathrm{~m}$ & 45,30 \\
\hline $\mathrm{I}: 0-1 \mathrm{~m}$ & 31,30 \\
\hline $\mathrm{III}: 2-5 \mathrm{~m}$ & 17,00 \\
\hline $\mathrm{IV}: 5-10 \mathrm{~m}$ & 5,30 \\
\hline $\mathrm{V}:>10 \mathrm{~m}$ & 1,10 \\
\hline
\end{tabular}

(b) tanaman pada keragaman vertikal (strata tanaman)

Gambar 3. Komposisi tanaman dalam pekarangan diklasifikasikan menjadi 8 kategori dan 5 strata. Tanaman dalam pekarangan didominasi oleh tanaman hias (ornamental) sebesar 49,01\% dan oleh tanaman dengan strata II (1-2 m) mencapai 45,30\%. 


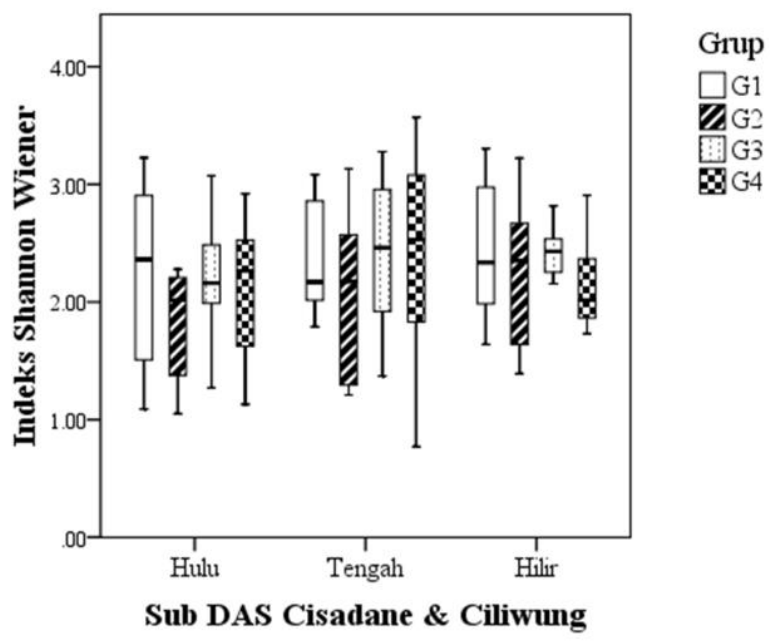

Gambar 4. Nilai Indeks Shannon-Wiener pada level hulutengah-hilir dan level grup G1, G2, G3 dan G4.

Keragaman tanaman dipengaruhi oleh perhatian masyarakat pada area pekarangannya. Penyediaan pekarangan bagi keluarga yang kekurangan lahan atau area budidaya dapat menolong keluarga tersebut untuk memperoleh bahan makanan dan bahan bakar dari area di sekelilingnya.

Pada akhirnya pekarangan senantiasa mempertahankan keragaman dan pada saat yang bersamaan juga melestarikan hutan di sekelilingnya (Mitchell and Hanstad 2004). Situasi ini membuat keragaman tanaman dapat terus meningkat, secara tidak langung. Keragaman yang tinggi dapat mempertahankan fluktuasi karbon dalam lingkungan (Henry et al. 2009), dengan demikian pekarangan dapat menjadi salah satu penjaga kestabilan jumlah $\mathrm{CO}_{2}$ di atmosfir.

\section{Kandungan Karbon Tersimpan dalam Pekarangan}

Karbon tersimpan dalam pekarangan berkisar 0,13 hingga $90,80 \mathrm{Mg} /$ ha di dalam pekarangan berukuran kecil (G1 dan G2), sementara untuk pekarangan berukuran sedang (G3 dan G4) lebih tinggi berkisar 0,18 hingga 136,20 Mg/ha (Gambar 6). Secara total, rata-rata karbon tersimpan dalam pekarangan mencapai $22,26 \mathrm{Mg} / \mathrm{ha}$. Hasil perhitungan juga menunjukkan bahwa karbon tersimpan dalam pekarangan dapat mencapai hingga $20 \%$ dari karbon tersimpan total dari kandungan karbon tersimpan di dalam hutan alami. Hal ini berarti bahwa kepadatan dan pertumbuhan tanaman di dalam pekarangan memiliki kemampuan untuk menyerupai (mimic) kondisi hutan alami. Dalam konteks karbon tersimpan, terdapat korelasi nyata antar grup, walaupun demikian tidak terdapat korelasi antara pekarangan yang memiliki OAL dan tidak memiliki OAL. Rata-rata karbon tersimpan pada pekarangan bagian tengah DAS Cisadane cenderung lebih tinggi $(26,11 \mathrm{Mg} / \mathrm{ha})$, sama

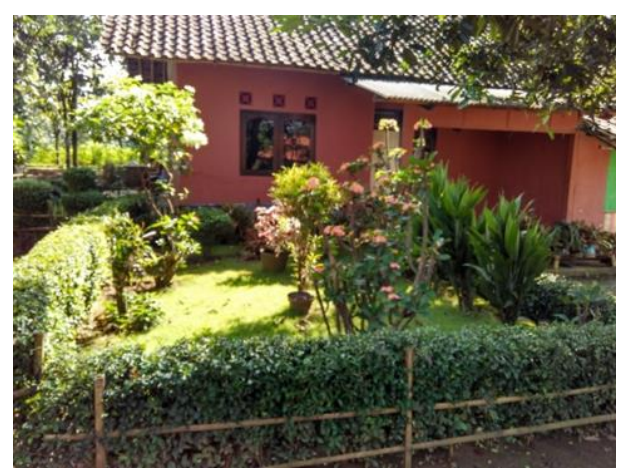

a) Pekarangan bagian depan rumah

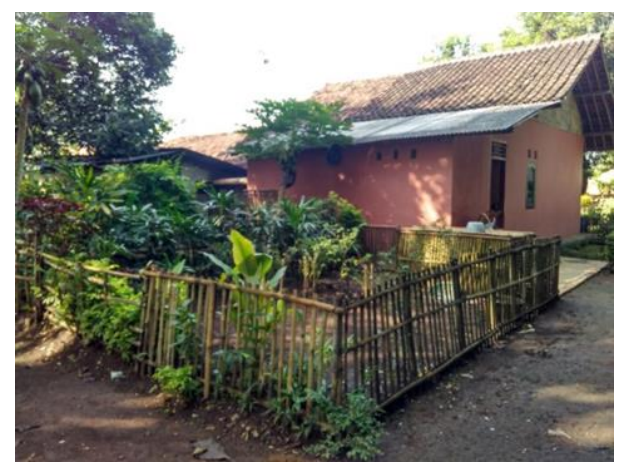

b) Pekarangan bagian belakang rumah. Nilai Indeks Shannon Wiener $=2,99$

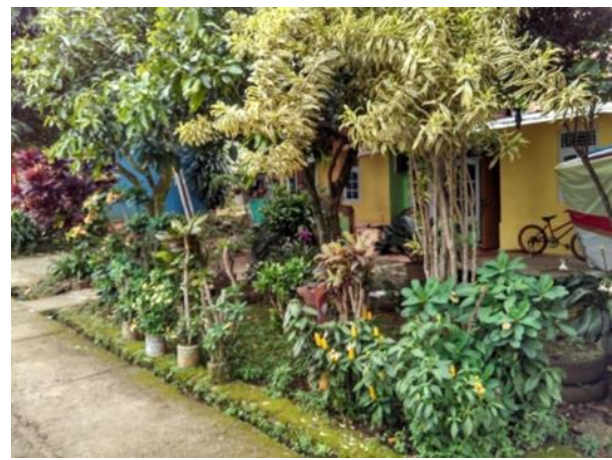

c) Contoh pekarangan G4 pada bagian tengah DAS Cisadane dengan $\mathrm{H}^{\prime}=2.97$

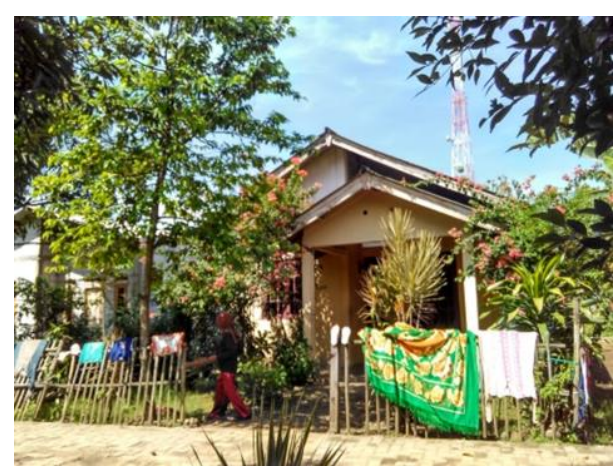

d)Contoh Pekarangan G1 pada bagian tengah DAS Cisadane dengan nilai $\mathrm{H}^{\prime}=2,73$

Gambar 5. Contoh pekarangan dengan nilai $\mathrm{H}^{\prime}$ tingkat sedang $\left(1<\mathrm{H}^{\prime}<3\right)$. 
halnya dengan nilai indeks keanekaragaman. Secara keseluruhan pekarangan yang memiliki karbon tersimpan $>10.00 \mathrm{Mg} /$ ha mencapai $45,83 \%$ dari total sampel. Rata-rata di bagian hulu sama dengan $18,70 \mathrm{Mg} / \mathrm{ha}$, dan di bagian hilir sama dengan $21,96 \mathrm{Mg} / \mathrm{ha}$.

Hal yang menyebabkan karbon tersimpan di daerah tengah DAS Cisadane cenderung lebih tinggi yaitu keberadaan pohon-pohon besar. Salah satu pekarangan dengan nilai karbon tersimpan yang tinggi, di dalamnya terdapat beberapa pohon besar dengan diameter setinggi dada lebih dari $10 \mathrm{~cm}$ sampai $41 \mathrm{~cm}$ (Gambar 7). Karbon tersimpan yang berada di atas permukaan tanah terdapat pada tanaman khususnya pada tanaman tahunan (Henry et al. 2009). Karbon tersimpan tersebut dipengaruhi oleh struktur dan komposisi dari vegetasi seperti jenis, ukuran, tinggi dan masa jenis pohon (Bajigo et al. 2015).

Salah satu pekarangan pada grup G3 di bagian tengah DAS Cisadane menyimpan karbon sebesar 108,52 $\mathrm{Mg} /$ ha. Pohon besar seperti mangga, rambutan dan jambu biji yang terdapat di pekarangan ini menyumbang hampir $95,32 \%$ yaitu $103,44 \mathrm{Mg} / \mathrm{ha}$. Secara keseluruhan karbon dapat tersimpan di bagian tumbuhan atas tanah, serasah, herba, tanah dan akar. Biomasa tumbuhan di atas tanah berpotensi menyimpan $32,9 \%$ dari seluruh total, dan tanah dapat mencapai $56,7 \%$ (Roshetko et al. 2002). Praktek agroforestri akan membedakan jumlah karbon yang dapat tersimpan, hal ini terkait dengan komposisi spesies dan perbedaan variasi ekologi dan lingkungan (Kumar 2011). Hal lainnya adalah kecepatan tumbuh pohon dan jumlah pohon per satuan lahan ((

Secara umum pekarangan yang membudidayakan pohon pasti akan menyimpan karbon jauh lebih tinggi (Gambar 7). Hal tersebut menjadi salah satu alasan karbon tersimpan pada pekarangan tanpa OAL lebih tinggi dari pekarangan dengan OAL. Namun, kepemilikan OAL secara nyata mempengaruhi jumlah karbon tersimpan dalam pekarangan, hal ini karena pekarangan tanpa OAL lebih memperhatikan tanaman hias (ornamental) yang secara ekonomis lebih menguntungkan namun memiliki kandungan karbon yang rendah. Di sisi lain, dapat dikatakan bahwa pekarangan yang berukuran kecil dan sedang $\left(<400 \mathrm{~m}^{2}\right)$ ternyata juga memiliki potensi kandungan karbon tersimpan yang sangat tinggi.

Pohon dari spesies yang pertumbuhannya lambat lebih tinggi massa jenis kayunya daripada spesies yang cepat tumbuh, oleh karena itu spesies yang lama tumbuh dapat mengakumulasi karbon dalam jangka waktu yang lama (Baker et al. 2004). Beberapa contoh pohon dengan masa jenis kayu tinggi yaitu lebih dari $800 \mathrm{~kg} / \mathrm{m}^{3}$ adalah pohon yang dimanfaatkan kayunya untuk furniture atau industri lainnya seperti pohon jati (Tectona grandis),

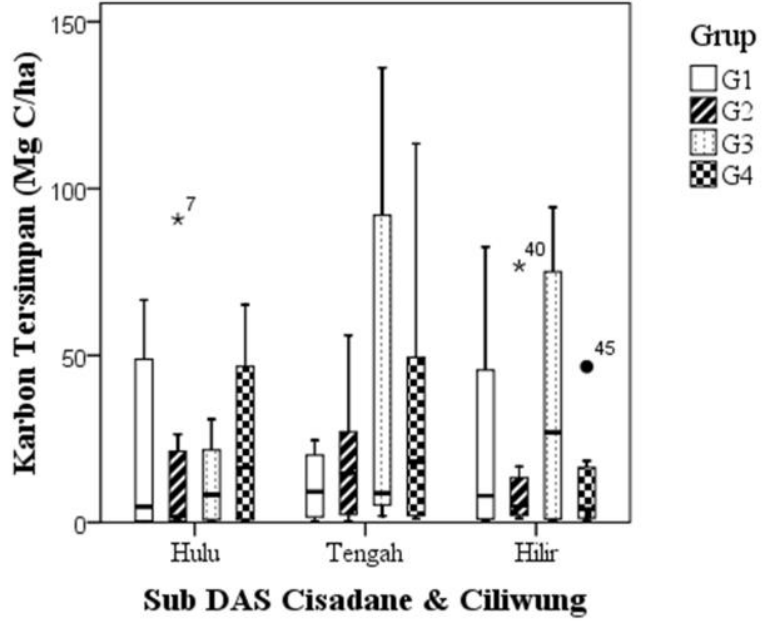

Gambar 6. Jumlah karbon tersimpan dari tanaman ( $\mathrm{Mg} / \mathrm{ha}$ atau ton/ha) di dalam pekarangan berdasarkan klasifikasi sub-das dan grup. Terlihat bahwa pekarangan pada skala kecil juga memiliki kemampuan untuk menyimpan karbon dalam jumlah yang besar

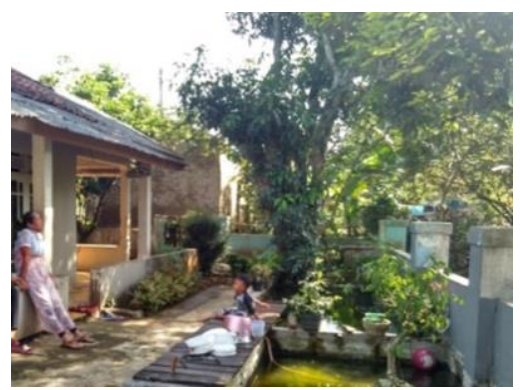

a

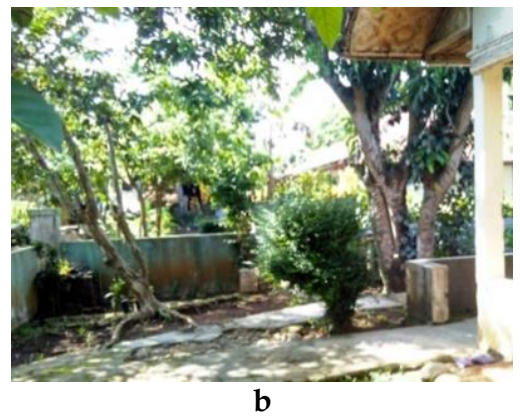

Salah satu contoh pekarangan G3 dengan jumlah karbon $108,52 \mathrm{Mg} \mathrm{C} /$ ha. Pekarangan bagian depan (a) dan

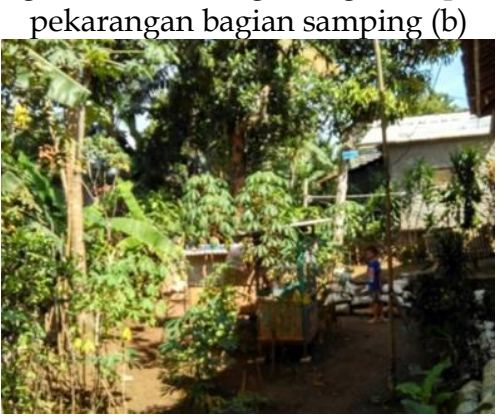

Pekarangan tanpa OAL (G3) dengan jumlah karbon 131,61 $\mathrm{Mg} \mathrm{C} / \mathrm{ha}$

Gambar 7. Contoh pekarangan G3 dengan kandungan karbon yang tinggi. Kandungan karbon tinggi diperoleh karena adanya penanaman pohon. 
KASWANTO, FILQISTHI, CHOLIQ

merbau (Intsia bijuga), atau meranti (Shorea javanica). Jenis pohon lokal yang sering ditanam pada pekarangan dan memiliki masa jenis sedang yaitu kayu manis (Cinnamomum burmanii). Masyarakat menggunakan tanaman ini sebagai obat dan juga bumbu dapur. Secara umum masyarakat lebih sering menanam pohon buah-buahan seperti mangga, rambutan, durian, dan nangka. Tentunya masa jenis pohon buah tidak setinggi pohon penghasil kayu. Walau demikian pemilik rumah dapat menanam kedua jenis pohon ini sesuai kebutuhan. Seperti buah untuk konsumsi atau kayu untuk pendapatan tambahan. Selain itu ditemukan juga beberapa jenis tanaman eksotik khususnya tanaman-tanaman hias. Tanaman eksotik akan lebih cepat tumbuh dan berkembang biak, dan tentunya akan berkontribusi dalam penyerapan karbon. Namun, keberadaan tanaman eksotik terkait karbon tersimpan di lanskap agroforestri masih diperdebatkan. Tanaman lokal lebih mudah beradaptasi daripada tanaman eksotik (Nair et al. 2009). selain itu tanaman eksotik akan lebih berbahaya terlebih jika berada di dekat area konservasi (Kaswanto and Nakagoshi 2014, Bajigo et al. 2015).

\section{Korelasi Indeks Biodiversitas Tanaman dan Karbon Tersimpan}

Analisis korelasi dilakukan untuk melihat keterhubungan antara indeks biodiversitas dengan karbon tersimpan pada lanskap pekarangan. Pengelolaan jasa lanskap berupa biodiversitas dan karbon tersimpan di pekarangan harus berkelanjutan dalam waktu yang panjang, sehingga mempelajari hubungan kedua hal tersebut menjadi penting. Hipotesanya adalah pekarangan dengan jumlah vegetasi yang banyak akan mampu menyimpan karbon yang banyak pula.

Hasil uji regresi linier Indeks Shannon Wiener dengan karbon tersimpan adalah berhubungan positif (Gambar 8 ) dengan $R^{2}=0,2344$. Hubungan antara indeks Shannon Wiener khusus dari jenis tanaman pohon saja dengan karbon tersimpannya memiliki nilai yang lebih besar yaitu $R^{2}=0,871$. Variasi karbon tersimpan tidak berpengaruh dengan biodiversitas tanaman. Hasil ini sejalan dengan hasil penelitian Mandal et al (2013) dan Karna (2012).

Jenis pohon dan komposisi pada lahan agroforestri lebih mempengaruhi kualitas serta kuantitas biomasa pada tanah dan tentu saja karbon tersimpan di bawah permukaan tanah (Nair et al. 2009). Beberapa hal yang mempengaruhinya adalah ketersediaan air, kualitas dan kuantitas serasah, komposisi akar, dan distribusi karbon pada profil tanah. Penelitian terbaru (Dayamba et al. 2016) menemukan hubungan positif antara biodiversitas dengan biomassa karbon bawah tanah di daerah Afrika Barat.

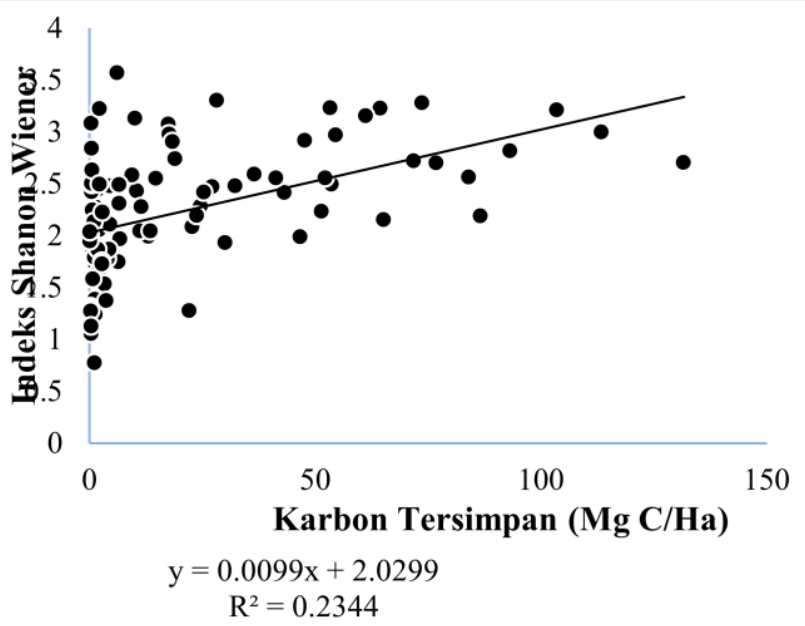

Gambar 8. Grafik korelasi antara Indeks Shannon Wiener dengan Karbon Tersimpan. Korelasi keduanya positif dengan $\mathrm{R}^{2}=0,2344$.

\section{Manajemen Lanskap Pekarangan sebagai Penyedia Jasa Lanskap}

Dalam konteks produktivitas, G1 dan G2 berbeda nyata dengan G3 dan G4, yang artinya pekarangan berukuran kecil lebih produktif dibandingkan pekarangan berukuran sedang. Hal ini dikarenakan pengelolaan pekarangan berukuran kecil lebih intensif dibandingkan pekarangan berukuran sedang. Pekarangan kecil (G1 dan G2) cenderung mengembangkan area terbukanya dengan membudidayakan lebih banyak tanaman pangan dan berupaya lebih banyak memelihara hewan ternak/ikan. Kecenderungan ini juga dikarenakan mereka tidak memiliki lahan lain yang bisa mereka kelola, sehingga mereka lebih berfokus pada pekarangan mereka sendiri. Grup pekarangan tanpa OAL cenderung untuk memiliki pedapatan lebih tinggi dari pekarangan dibandingkan dengan Grup yang memiliki OAL, karena pekarangan tanpa OAL akan selalu mencoba untuk mengembangkan dan meningkatakn produktivitas pekarangan, hal ini sejalan dengan penjelasan yang telah diutarakan di awal tulisan ini.

Mitchell et al. (2004) juga menyebutkan bahwa pekarangan berkontribusi secara nyata dalam banyak cara dan secara signifikan meningkatkan status finansial keluarga. Lebih lanjut dikatakan bahwa pekarangan tidak hanya berperan secara ekologi saja, namun juga fungsi sosial dan budaya (Arifin et al. 2001). Pekarangan berukuran kecil harus dipertimbangkan sebagai sebuah model untuk keberlanjutan sistem agroforestri skala mikro, mengintegrasikan benefit ekonomi dan ekologi yang mampun meningkatkan kesejahteraan masyarakat untuk masa depan yang ebih baik, seperti yang dikemukakan oleh Schultink (2000). Pekarangan juga mampu berkontribusi untuk meningkatkan kesejahteraan rumah tangga, hal ini sejalan dengan beberapa penelitian terdahulu (Albrecht and Kandji 2003, Harash- 
ina et al. 2003, Kabir and Webb 2008, Mulyoutami et al. 2009). Pada akhirnya, pekarangan harus dikelola secara lebih efektif fan efisien untuk mengoptimalkan potensi jasa lanskap yang ada di dalamnya. Pekarangan seharusnya dikembangkan lebih intensif untuk dapat memiliki biodiversitas $\left(\mathrm{H}^{\prime}>3\right)$ dan kandungan karbon yang tinggi $(\mathrm{C}>20 \mathrm{Mg} / \mathrm{ha})$ agar dapat menjadi aset ekonomi bagi pemiliknya. Selain itu, pekarangan juga harus direkomendasikan sebagai salah satu strategi untuk mengatas malnutrisi dan defisiensi nutrisi mikro, khususnya bagi masyarakat di area marjinal. Beberapa studi juga menemukan bahwa pekarangan secara signifikan meningkatkan konsumsi rumah tangga (Niñez 1985, Soemarwoto 1987, Marsh 1998, Mitchell and Hanstad 2004, Abdoellah et al. 2006, Wiersum 2006).

\section{SIMPULAN}

Sebagian besar struktur pekarangan memiliki biodiversitas tanaman dengan nilai $\mathrm{H}^{\prime}$ berkisar 0,77 3,57, dan nilai $H^{\prime}>1,00$ mencapai $98,95 \%$ dari total sampel pekarangan. Rataan $\mathrm{H}^{\prime}$ pada pekarangan tanpa OAL (G1\&G3) lebih tinggi daripada pekarangan dengan OAL (G2\&G4). Hal ini menunjukkan bahwa, dengan tidak adanya OAL akan membuat pemilik rumah memanfaatkan lahan pekarangannya secara lebih intensif, sehingga membuat $\mathrm{H}^{\prime}$ pada pekarangan tanpa OAL lebih tinggi. Nilai $\mathrm{H}^{\prime}$ yang tinggi menjadikan pekarangan memiliki potensi yang amat baik untuk menyediakan jasa lanskap biodiversitas tanaman.

Begitu pula dengan kandungan karbon tersimpan, terlebih jika tanaman yang dipilih berupa pohon yang memiliki massa jenis tinggi. Kepemilikan OAL mempengaruhi jumlah karbon tersimpan dalam pekarangan, hal ini karena pekarangan dengan OAL lebih memilih untuk menanam berbagai jenis pohon dibandingkan dengan pekarangan tanpa OAL yang lebih memperhatikan tanaman hias yang secara ekonomis lebih menguntungkan namun memiliki kandungan karbon yang rendah. Di sisi lain, pekarangan sampel yang luasannya $<400 \mathrm{~m}^{2}$ (G2\&G4) ternyata juga memiliki potensi kandungan karbon tersimpan yang sangat tinggi. Dengan demikian, dapat dikatakan bahwa pekarangan akan berfungsi baik sebagai penyimpan kandungan karbon dengan rata-rata lebih dari $20 \mathrm{Mg} /$ ha.

Berdasarkan perhitungan biodiversitas tanaman dan kandungan karbon tersimpan pada pekarangan, maka rekomendasi dalam manajemen agar pekarangan mampu menyediakan jasa lanskap dengan baik adalah 1) komposisi dan jenis tanaman perlu diperhatikan agar pekarangan memiliki $\mathrm{H}^{\prime}$ yang tinggi, 2) pekarangan dengan $\mathrm{H}^{\prime}$ tinggi seharusnya disertai dengan kandungan karbon tersimpan yang optimal, artinya keberadaan pohon menjadi penting karena keefektifannya dalam menyimpan karbon, dan 3) pekarangan sejatinya perlu menjadi pertimbangan masyarakat tidak hanya sebagai aset secara tangible namun juga intangible. Disisi lain, terkait dengan konsep lanskap rendah karbon maka direkomendasikan tiga hal yang perlu segera diimplementasikan, yakni mengoptimalkan lahan pekarangan, menanam tanaman yang produktif, serta menanam tanaman lokal.

Lanskap agroforestri skala mikro dalam bentuk pekarangan dapat berkontribusi secara nyata dalam menyediakan jasa lanskap. Jasa lanskap dimanfaatkan untuk melestarikan lingkungan sekitarnya dan pada saat yang bersamaan juga menjadi aset bagi pemiliknya dalam meningkatkan kesejahteraan rumah tangga. Pelestarian lanskap pekarangan dari aspek biodiversitas tanaman dan kandungan karbon mampu memberikan nilai tambah bagi kualitas lanskap perdesaan. Oleh karena itu, revitalisasi pekarangan dengan meningkatkan jasa lanskap sebagai aset bagi masyarakat perdesaan perlu lebih diberdayakan. Masyarakat harus mempertimbangkan praktek agroforestri pekarangan yang sesuai daripada hanya mengandalkan budidaya lahan pertanian semata. Masyarakat juga bisa berharap banyak dengan merevitalisasi penggunaan spesies lokal secara beragam demi meningkatkan nilai ekologis, ekonomi dan sosial.

\section{UCAPAN TERIMA KASIH}

Penulis mengucapkan banyak terima kasih kepada Kementerian Ristek Dikti pada program Penelitian Unggulan Perguruan Tinggi (PUPT) dalam skim Penelitian Strategis Aplikasi (PSA) yang bertopik Manajemen Lanskap Agroforesri sebagai Penyedia Jasa Lanskap dalam Mewujudkan Masyarakat Rendah Karbon (Low Carbon Society - LCS). Terima kasih juga disampaikan kepada BPDAS Ciliwung Cisadane atas bantuan dan kerjasamanya.

\section{DAFTAR PUSTAKA}

Abdoellah, O., H. Hadikusumah, K. Takeuchi, S. Okubo, and Parikesit. 2006. Commercialization of homegardens in an Indonesian village: Vegetation composition and functional changes. Pages 233250 in B. Kumar and P. Nair, editors. Tropical Homegardens. Springer Netherlands.

Albrecht, A., and S. T. Kandji. 2003. Carbon sequestration in tropical agroforestry systems. Agriculture, Ecosystems \& Environment 99:13. 
Ali, A., M.-S. Xu, Y.-T. Zhao, Q.-Q. Zhang, L.-L. Zhou, X.-D. Yang, and E.-R. Yan. 2015. Allometric biomass equations for shrub and small tree species in subtropical China.

Arifin, H. S., R. L. Kaswanto, and N. Nakagoshi. 2014. Low Carbon Society Through Pekarangan, Traditional Agroforestry Practices in Java, Indonesia. Pages 129-143 in N. Nakagoshi and J. A. Mabuhay, editors. Designing Low Carbon Societies in Landscapes. Springer Japan.

Arifin, H. S., and N. Nakagoshi. 2011. Landscape ecology and urban biodiversity in tropical Indonesian cities. Landscape and Ecological Engineering 7:33-43.

Arifin, H. S., K. Sakamoto, and T. Takeuchi. 2001. Study of rural landscape structure based on its different bio-climatic conditions in middle part of Citarum Watershed, Cianjur District, West Java, Indonesia. Pages 99-108 in JSPS-DGHE Core University Program in Applied Biosciences. The University of Tokyo, Japan, Tokyo.

Backes, M. M. 2001. The role of indigenous trees for the conservation of biocultural diversity in traditional agroforestry land use systems: The Bungoma case study: In-situ conservation of indigenous tree species. Agroforestry Systems 50:119-132.

Bajigo, A., M. Tadesse, Y. Moges, and A. Anjulo. 2015. Estimation of Carbon Stored in Agroforestry Practices in Gununo Watershed, Wolayitta Zone, Ethiopia. Journal of Ecosystem \& Ecography 5:1.

Baker, T. R., O. L. Phillips, Y. Malhi, S. Almeida, L. Arroyo, A. Di Fiore, T. Erwin, T. J. Killeen, S. G. Laurance, and W. F. Laurance. 2004. Variation in wood density determines spatial patterns inAmazonian forest biomass. Global Change Biology 10:545-562.

Brown, S., Food, and A. O. o. t. U. Nations. 1997. Estimating Biomass and Biomass Change of Tropical Forests: A Primer. Food and Agriculture Organization of the United Nations.

Chave, J., C. Andalo, S. Brown, M. A. Cairns, J. Q. Chambers, D. Eamus, H. Fölster, F. Fromard, N. Higuchi, T. Kira, J.-P. Lescure, B. W. Nelson, H. Ogawa, H. Puig, B. Riéra, and T. Yamakura. 2005. Tree allometry and improved estimation of carbon stocks and balance in tropical forests. Oecologia 145:87-99.

Christanty, L. 1986. Shifting cultivation and tropical soils: patterns, problems, and possible improvements.in In Marten GG. Citeseer.
Christanty, L. 1990. Home Gardens in Tropical Asia, with Special Reference to Indonesia. Pages 9-20 in K. Landauer and M. Brazil, editors. Tropical Home Gardens. The United National University, Tokyo, Japan.

Christanty, L., O. S. Abdoellah, G. G. Marten, and J. Iskandar. 1986. Traditional agroforestry in West Java: the pekarangan (homegardens) and kebun talun (annual-perennial rotation) cropping systems. Pages 132-158 in G. G. Marten, editor. Traditional agriculture in South-east Asia. Westview, Boulder.

Dayamba, S. D., H. Djoudi, M. Zida, L. Sawadogo, and L. Verchot. 2016. Biodiversity and carbon stocks in different land use types in the Sudanian Zone of Burkina Faso, West Africa. Agriculture, Ecosystems \& Environment 216:61-72.

Hairiah, K., and S. Rahayu. 2007. Pengukuran karbon tersimpan di berbagai macam penggunaan lahan. Bogor. World Agroforestry Centre-ICRAF, SEA Regional Office, University of Brawijaya, Unibraw, Indonesia.

Harashina, K., K. Takeuchi, A. Tsunekawa, and H. S. Arifin. 2003. Nitrogen flows due to human activities in the Cianjur-Cisokan watershed area in the middle Citarum drainage basin, West Java, Indonesia: a case study at hamlet scale. Agriculture Ecosystems \& Environment 100:75-90.

Henry, M., P. Tittonell, R. J. Manlay, M. Bernoux, A. Albrecht, and B. Vanlauwe. 2009. Biodiversity, carbon stocks and sequestration potential in aboveground biomass in smallholder farming systems of western Kenya. Agriculture, Ecosystems \& Environment 129:15p.

Hochegger, K. 1998. Farming like the Forest-Traditional Home Garden System in Sri Lanka. Margraf Weikersheim, Germany.

Hylander, K., and S. Nemomissa. 2009. Complementary Roles of Home Gardens and Exotic Tree Plantations as Alternative Habitats for Plants of the Ethiopian Montane Rainforest. Conservation Biology 23:10p.

Kabir, M. E., and E. L. Webb. 2008. Can homegardens conserve biodiversity in Bangladesh? Biotropica 40:95-103.

Karna, Y., Y. Hussin, M. Bronsveld, and B. S. Karky. 2012. Mapping above ground carbon using worldview satellite image and lidar data in relationship with tree diversity of forests. The Netherlands: Master's thesis, Faculty of Geoinformation Science and Earth Observation, University of Twente. 
Karyono. 1990. Homegardens in Java: Their Structure and Function.in L. K and B. M, editors. Tropical Homegardens. United Nations University Press Tokyo.

Kaswanto, M. Baihaqi, and A. A. Hadi. 2013. Potensi Pekarangan dalam Peningkatan Jasa Lanskap di Kawasan Perdesaan. Pages 442-452 in Prosiding Lokakarya dan Seminar FKPTPI, Bogor.

Kaswanto, and N. Nakagoshi. 2011. Landscape Ecology based Approach for Assessing Pekarangan Condition to Preserve Protected Areas in West Java. Proceeding of the 8th International Association for Landscape Ecology (IALE) World Congress CDROM. IALE Organizing Committee, Beijing, China.

Kaswanto, R. L., and N. Nakagoshi. 2014. Landscape Ecology-Based Approach for Assessing Pekarangan Condition to Preserve Protected Area in West Java. Pages 289-311 in N. Nakagoshi and J. A. Mabuhay, editors. Designing Low Carbon Societies in Landscapes. Springer Japan.

Kumar, B. M. 2011. Species richness and aboveground carbon stocks in the homegardens of central Kerala, India. Agriculture, Ecosystems \& Environment 140:430-440.

Landauer, K., and M. Brazil. 1990. Tropical Home Gardens. Page 255 United Nation University Press, Tokyo, Japan.

Mandal, R. A., I. C. Dutta, P. K. Jha, and S. Karmacharya. 2013. Relationship between carbon stock and plant biodiversity in collaborative forests in Terai, Nepal. ISRN Botany 2013.

Marsh, R. 1998. Building on Traditional Gardening to Improve Household Food Security. Food, Nutrition and Agriculture No. 22. Food and Agriculture Organization.

Méndez, V. E., R. Lok, and E. Somarriba. 2001. Interdisciplinary analysis of homegardens in Nicaragua: micro- zonation, plant use and socioeconomic importance. Agroforestry Systems 51:85-96.

Mitchell, R., and T. Hanstad. 2004. Small homegarden plots and sustainable livelihoods for the poor. Access to Natural Resources Sub-Programme. Rural Development Institue (RDI), USA.

Moreno-Black, G., P. Somnasang, and S. Thamathawan. 1996. Cultivating continuity and creating change: Women's home garden practices in northeastern Thailand. Agriculture and Human Values 13:3-11.

Mpoyi, K., N. Lukebakio, K. Kapende, and J. Paulus. 1994. Inventaire de la flore domestique des par- celles d'habitation. Cas de Kinshasa (Zaire). Revue de Medecine et Pharmacopee Africaine 8:55-66.

Mulyoutami, E., R. Rismawan, and L. Joshi. 2009. Local knowledge and management of simpukng (forest gardens) among the Dayak people in East Kalimantan, Indonesia. Forest Ecology and Management 257:2054-2061.

Nair, P. R., V. D. Nair, B. M. Kumar, and S. G. Haile. 2009. Soil carbon sequestration in tropical agroforestry systems: a feasibility appraisal. Environmental Science \& Policy 12:1099-1111.

Niñez, V. 1985. Introduction: Household gardens and small-scale food production.in V. Niñez, editor. Food and Nutrition Bulletin. International Potato Centre (CIP).

Niñez, V. 1987. Household gardens: Theoretical and policy considerations. Agricultural Systems 23:167186.

Padoch, C., and W. de Jong. 1991. The house gardens of Santa Rosa: Diversity and variability in an Amazonian agricultural system. Economic Botany 45:166-175.

Roshetko, J., R. Lasco, and M. Angeles. 2007. Smallholder agroforestry systems for carbon storage. Mitigation and Adaptation Strategies for Global Change 12:219-242.

Roshetko, J. M., M. Delaney, K. Hairiah, and P. Purnomosidhi. 2002. Carbon stocks in Indonesian homegarden systems: Can smallholder systems be targeted for increased carbon storage? American Journal of Alternative Agriculture 17:138-148.

Schultink, G. 2000. Critical environmental indicators: performance indices and assessment models for sustainable rural development planning. Ecological Modelling 130:47-58.

Soemarwoto, O. 1987. Homegardens: A traditional agroforestry system with promising future. Pages 157170 in H. A. Steppler and P. K. R. Nair, editors. A Decade of Development. ICRAF, Nairobi.

Soemarwoto, O., and G. R. Conway. 1992. The Javanese homegarden. Journal for Farming Systems Research-Extension 2:95-118.

Wiersum, K. 2006. Diversity and change in homegarden cultivation in Indonesia. Pages 13-24 in B. Kumar and P. Nair, editors. Tropical Homegardens. Springer, Dordrecht. 